\title{
SEBERAPA EFEKTIFKAH PEMBERANTASAN DBD DENGAN INSEKTISIDA?
}

\author{
Lusiyana $\mathrm{N}^{1}$
}

${ }^{1}$ Departemen Parasitologi Fakultas Kedokteran Universitas Islam Indonesia

Nyamuk Aedes aegypti merupakan vektor utama penyakit Demam dengue dan Demam berdarah dengue (DBD). ${ }^{1}$ Berbagai strategi untuk mengendalikan nyamuk ini telah banyak dilakukan yang bertujuan untuk memutus rantai penularan penyakit yang ditularkan oleh nyamuk sebagai vektor penyakit. Nyamuk Ae. aegypti sendiri harus dikendalikan karena kepadatan populasi Ae. aegypti dikaitkan dengan penularan, endemisitas, dan Kejadian luar biasa (KLB). ${ }^{2}$ Pengendalian yang paling populer saat ini adalah pengendalian secara kimiawi dengan menggunakan insektisida.

Di Indonesia upaya pengendalian nyamuk Ae. aegypti sangat tergantung pada penggunaan insektisida. Insektisida banyak digunakan karena dipandang lebih efektif dan hasilnya cepat terlihat bila dibandingkan pengendalian secara biologis. Namun penggunaan insektisida ini mempunyai dampak negatif berupa resistensi. ${ }^{3}$ Di berbagai belahan dunia, penggunaan insektisida telah banyak dilaporkan menimbulkan resistensi. Insektisida yang telah resisten seperti golongan piretroid, sipermetrin, deltametrin dan permetrin. ${ }^{4,5,6,7}$ Resistensi serangga terhadap insektisida umumnya terjadi setelah masa penggunaan 2-20 tahun. ${ }^{8}$

Munculnya galur nyamuk Ae. aegypti resisten dipicu oleh adanya pajanan yang berlangsung lama terhadap insektisida tertentu. Hal ini terjadi karena nyamuk Ae. aegypti mampu mengembangkan sistem kekebalan terhadap insektisida yang sering dipakai. Nyamuk juga mampu meningkatkan produksi enzim detoksifikasi seperti esterase, glutatione S-transverase dan modifikasi reseptor insektisida. ${ }^{9}$ Beberapa penelitian menunjukkan pula adanya resistensi silang, yaitu timbulnya resistensi terhadap suatu insektisida karena pajanan oleh insektisida lainnya. ${ }^{10}$

Resistensi terhadap insektisida kimia bersifat multifaktorial seperti dipengaruhi oleh faktor lingkungan, durasi, dosis dalam aplikasi insektisida dan faktor genetik (gen metabolik dan reseptor insektisida dalam tubuh nyamuk). ${ }^{10}$ Penggunaan insektisida yang 
tidak terkontrol di masyarakat pada akhirnya dapat menimbulkan dampak berupa resistensi tersebut, sehingga perlu adanya pemantauan dari pihak terkait terhadap penggunaan insektisida di masyarakat.

\section{DAFTAR PUSTAKA}

1. WHO. Pencegahan dan Pengendalian Dengue dan Demam Berdarah Dengue. Panduan Lengkap., Jakarta, EGC. 2005

2. Departemen Kesehatan RI., 2010. Demam Berdarah Dengue di Indonesia Tahun 1968-2009. Buletin Jendela Epidemiologi. vol 2.

3. Panghiyangani R, Rahmiati, Ahda N. Potensi ekstrak daun dewa sebagai larvasida nyamuk Aedes aegypti vektor penyakit demam berdarah dengue. Jurnal Kedokteran Indonesia. 2009. 1(2):121-125.

4. Braga A, Lima JBP, Soares S, Valle A. Aedes aegypti resistance of temephos during 2001 in several municipalientes the state of Rio de Janeiro, Sergipe and Alagoas Brazil. Mem Inst Oswaldo Cruz, Rio de Janeiro. 2004. 99(2):199-203.

5. Ponlawat A, Scott JG, Harrington C. Insecticid susceptibility of Aedes aegypti and Aedes albopictus cross Thailand. J Med.Entomol. 2005. 2(5):821-825.

6. Brengues C, Hawkes NJ, Chandre F, McCarrol L, Duchon S, Guillet P, Maguin S, Morgan JC, Hemingway J. Pyretroid and DDT cross-resistance in Aedes aegypti correlated within mutation the voltage-gates sodium channel gene. J Med Vet Entomol. 2003. 7:8

7. Ahmad I, Astari S, Tan M. Resistance of Aedes aegypti (Diptera: Culicidae) in 2006 to Pyretroid Insecticide in Indonesia and its association with Oxidase and Esterase Levels. Pakistan Journal of Biological Science, 2007.10(20), 3688-3692.

8. Georghio GP, Melon RB. Pest Resistance to Pesticide. New York. Plenum Press.

9. Lima EP, Paiva MHS, de Araujo AP, da Silva EVG, da Silva UM, de Oliveira LN. Insecticide resistance in Aedes aegypti population freom Ceara, Brazil. Parasites \& Vector. 2011. 4:5.

10. Johnson, P.W. Chemical Resistance In Live Stock. Elizabeth Mc Arthur Argicultural Institute. Camden NSW.1998. 